\author{
L.M. Sugralina ${ }^{1}$, I.Ye. Rozhkovoy ${ }^{2}$, L.K. Salkeyeva ${ }^{1}$, Ye.V. Minayeva ${ }^{1}$, \\ Ye.K. Taishibekova ${ }^{1}$, A.V. Omasheva ${ }^{1}$, A.K. Salkeyeva ${ }^{3}$ \\ ${ }^{I}$ Ye.A. Buketov Karaganda State University, Kazakhstan; \\ ${ }^{2} L L P \ll$ Kazcentrelectroprovod», Karaganda, Kazakhstan; \\ ${ }^{3}$ Karaganda State Technical University, Kazakhstan \\ (E-mail: sugralinalm@yandex.ru)
}

\title{
Phenolytical modification of polyurethane elastomers as a method of obtaining multifunctional additives for road coal tar bitumen
}

\begin{abstract}
Modification of road bitumen by introducing multifunctional additives was studied in the article. Local domestic and industrial wastes of polyurethane polymers were used as a raw material for obtaining such additives. In order to determine the optimal conditions for modification and selection of effective reagent for the process the method of probabilistically deterministic of planning of experiment was applied. Optimal parameters of phenolytical modification of mixture of polyurethane elastomers for the purpose of synthesis of additives for road asphalt bitumen blends were found on the basis of the experimental data processing. Comparison between two methods for the preparation of bituminous mixtures allowed concluding that the introduction of the modifier directly at the beginning of the heat treatment of the parent material is more appropriate in the production of modified coal tar bitumen. The carried on tests of physical and mechanical properties of modified coal tar bitumen showed that the use of synthesized modifier allows significantly expanding the range of high performance and ensuring adhesion properties of the road coal tar bitumen. Conceptual scheme of possible production of modified coal tar bitumen by intensive technology was proposed.
\end{abstract}

Keywords: polyurethane elastomers, processing of polyurethane waste, phenolytical modification, coal tar bitumen, additives for asphalt blends.

In the refining industry along with the deepening of oil refining the most urgent problem is increasing the quality of petroleum products which include oxidized bitumen of road purpose. The need for high-quality bitumen increases especially due to the continuous growth of the vehicle fleet in the country, increasing traffic volume and capacity of vehicles, and as a consequence, a significant increase of dynamic loads on the pavement.

The application of bitumen produced from coal tar instead of traditional oil one is gradually implemented in our region.

Over the last decade in Kazakhstan, and especially in the Karaganda region, the number of household and industrial waste of polyurethane polymers was increased. This is due to both growing consumption of products made from this material and the organization of the polyurethanes production in Karaganda. It is obvious that the problem of waste disposal will escalate over time.

One of the possible ways of solving these problems is the recycling of polyurethane waste and the use of products of their modification as universal multifunctional additives in road coal tar bitumen to improve their performance $[1,2]$.

The aim of our work was to study the possibility of modifying bitumen of local production by introducing multifunctional polymeric additives that are elastomeric products of given molar mass, obtained from a mixture of polyurethanes of different types.

Three compounds such as phenol, ethylene glycol and succinic acid were chosen as the objects of study.

To find the optimal reaction mode and selection of the most effective reagent we used the method of probabilistically deterministic planning of experiment. We constructed planning matrix including five factors on four levels for carrying out a series of experiments. The type of material being processed, the main reactant, the process temperature and percentage ratio of reactant mass to material mass were chosen as influencing factors. Shore A hardness and inverse logarithm of the acidity constant $\mathrm{pK}_{\mathrm{a}}$, respectively, were selected as the numerical values that reflect the type of material and the main reagent.

The material mass equal to $9 \mathrm{~g}$ and the reaction time of 3 hours were chosen as constants. The experiment was carried on in test tubes equipped with a stirrer as a downward spiral. The heating was conducted in a tube furnace with temperature control of $\pm 1^{\circ} \mathrm{C}$.

The products obtained were treated with water to remove reagent excess and low molar mass watersoluble compounds, dried in a desiccator over concentrated sulphuric acid for one day. The result of the experiment was number-average molar mass of the polymers obtained. 
These data allowed us to select the reaction parameters under which the product can be obtained with a number-average molar mass in the 2500-3000 range.

Products with the lowest molar mass which the estimated value was 122 are obtained at interacting polyurethane of hardness equal to 10 with ethylene glycol at a maximum concentration and the maximum temperature. The ratio polyurethane : ethylene glycol was 1:1.25. Maximum calculated molar mass of the product was equal to 20122. This result can be obtained by reaction of polyurethane of hardness equal to 107 with succinic acid at ratio polyurethane : succinic acid equal to $1: 0.25$ at $130{ }^{\circ} \mathrm{C}$. However such products are impractical for usage as a modifier, as a low molar mass modifier is a viscous liquid compound at room temperature and under dissolution in the bitumen considerably reduces its viscosity and adhesion characteristics. The high molar mass product, in contrast, has a very high melting point and extremely low solubility in bitumen.

The samples obtained by reacting phenol with polyurethane elastomers based on both polyethers and polyesters exhibited optimal molar masses and structures. The following reaction parameters were selected for synthesis of control: treated polymer was a mixture of different types of urethane elastomers, reagent was phenol, the reaction temperature was $190^{\circ} \mathrm{C}$, and the ratio of reactant mass to mass elastomers was $1: 4$. The choice of phenol was accounted for several reasons. Firstly, the phenol has the greatest structural similarity to the coal tar components of the bitumen, which should provide good solubility of modifier and strengthen intermolecular interaction with bitumen modifier as well. Secondly, it was noted during the experiments that the polyurethanes interacted intensively with phenol, and were well dissolved into it at decreasing molar mass. Thirdly, the products obtained by reacting with phenol at room temperature are soft and easily expandable polymers and at cooling after melting they well adhere to all surfaces, including glass, which suggests the possibility of increasing the adhesive properties of bituminous binders.

The resulting modifier was a soft elastomeric polymer with a molar mass of 2800 and a low melting point. The molar mass was determined by cryoscopy method when dissolved in bromoform.

The sample showed good solubility in coal tar bitumen. To check the properties and development of the technology for obtaining modified bitumen we tested two methods. The first one was an addition of modifier melted to the finished bitumen melted as well at $100{ }^{\circ} \mathrm{C}$ and vigorous stirring. Dissolving in the bitumen product showed good solubility and was easily homogenized in bitumen modifier at concentrations up to $45 \%$. At concentrations above $50 \%$ separating began upon cooling. Increase of concentration up to $70 \%$ leads to separating even under stirring.

Samples of bitumen with different concentrations of modifier were prepared by this method. Physical and mechanical properties of modified bitumen such as penetration number at ambient and low temperatures, the hydrophobic properties, and adhesion to concrete were studied by standard laboratory methods [3, 4]. The test results are shown in Table 1.

T a b l e 1

\section{Results of laboratory tests of physical and mechanical properties} of the coal tar bitumen modified by the first method

\begin{tabular}{|c|c|c|c|c|}
\hline $\begin{array}{c}\text { Concentration } \\
\text { of modifier, } \%\end{array}$ & $\begin{array}{c}\text { Depth of needle } \\
\text { penetration } \\
\text { at } 25^{\circ} \mathrm{C}, 0.1 \mathrm{mkm}\end{array}$ & $\begin{array}{c}\text { Softening } \\
\text { temperature, }{ }^{\circ} \mathrm{C}\end{array}$ & $\begin{array}{c}\text { Temperature } \\
\text { of fragility, }{ }^{\circ} \mathrm{C}\end{array}$ & $\begin{array}{c}\text { Dynamic } \\
\text { viscosity, Pa } \times \mathbf{s}\end{array}$ \\
\hline 0 & 89 & 46 & -39 & 87 \\
\hline 5 & 88 & 47 & -40 & 90 \\
\hline 10 & 90 & 50 & -40 & 100 \\
\hline 20 & 95 & 54 & -46 & 106 \\
\hline 30 & 101 & 61 & -53 & 120 \\
\hline
\end{tabular}

As it is seen from Table 1 the addition of modifier leads to improved performance of coal tar bitumen. These data stated that the increase of the modifier concentration higher than 30 percent does not significantly improve the properties and therefore further increase in concentration is inappropriate.

According to the analysis data we can also suggest a significant expansion of the temperature interval of laying and operation of asphalt pavement. Rise of the softening temperature and reducing temperature of fragility indicates about this. 
By the second method for producing bitumen modified polymeric additive is introduced directly into the process of production of bitumen from coal tar. Addition of modifier was produced in the same manner as in the subsequent mixing of components. Modifier concentration was from 5 to $40 \%$ with the same intervals as at the first case. Results of investigation are presented in Table 2.

Table 2

\section{Results of laboratory tests of physical and mechanical properties of the coal tar bitumen modified by the second method}

\begin{tabular}{|c|c|c|c|c|}
\hline $\begin{array}{c}\text { Concentration } \\
\text { of modifier, } \%\end{array}$ & $\begin{array}{c}\text { Depth of needle } \\
\text { penetration } \\
\text { at } 25^{\circ} \mathrm{C}, 0.1 \mathrm{mkm}\end{array}$ & $\begin{array}{c}\text { Softening } \\
\text { temperature, }{ }^{\circ} \mathrm{C}\end{array}$ & $\begin{array}{c}\text { Temperature } \\
\text { of fragility, }{ }^{\circ} \mathrm{C}\end{array}$ & $\begin{array}{c}\text { Dynamic } \\
\text { viscosity, Pa } \times \mathrm{s}\end{array}$ \\
\hline 0 & 89 & 46 & -39 & 87 \\
\hline 5 & 89 & 49 & -40 & 90 \\
\hline 10 & 90 & 53 & -41 & 91 \\
\hline 20 & 93 & 58 & -48 & 95 \\
\hline 30 & 97 & 66 & -55 & 110 \\
\hline 40 & 106 & 66 & $-55,5$ & 97 \\
\hline
\end{tabular}

When comparing the data in Tables 1 and 2 we can see that the second method for preparing the modified bitumen is more efficient than the conventional mixing of the components. This is because during prolonged thermal action more homogeneous medium was formed; this resulted in close intermolecular interactions between components of bitumen and modifier. The possibility of proceeding of various chemical reactions between bitumen and modifier is also not excluded.

Based on results obtained we can conclude that to produce a modified bitumen by introducing modifier directly at the beginning of heat treatment of the feedstock is more appropriate way.

There is a method for the production of bitumen from coal tar which is a by-product of «Sary Arka Spetskoks» plant [5]. Coal tar is a mixture of predominantly bi- and polycyclic aromatic hydrocarbons, and polycyclic systems with hetero atoms in the rings. The amount of these compounds is about $95 \%$ of the coal tar components. Consideration of coal tar as a physical and chemical system opens up new possibilities for the study of its properties and improving its processing technology. The coal tar of Shubarkol coal mine contains about $10 \%$ phenol, $2.3 \%$ of organic bases of preferably acridine and quinoline series.

Figure 1 shows a technology diagram of a laboratory reactor for producing coal tar bitumen.

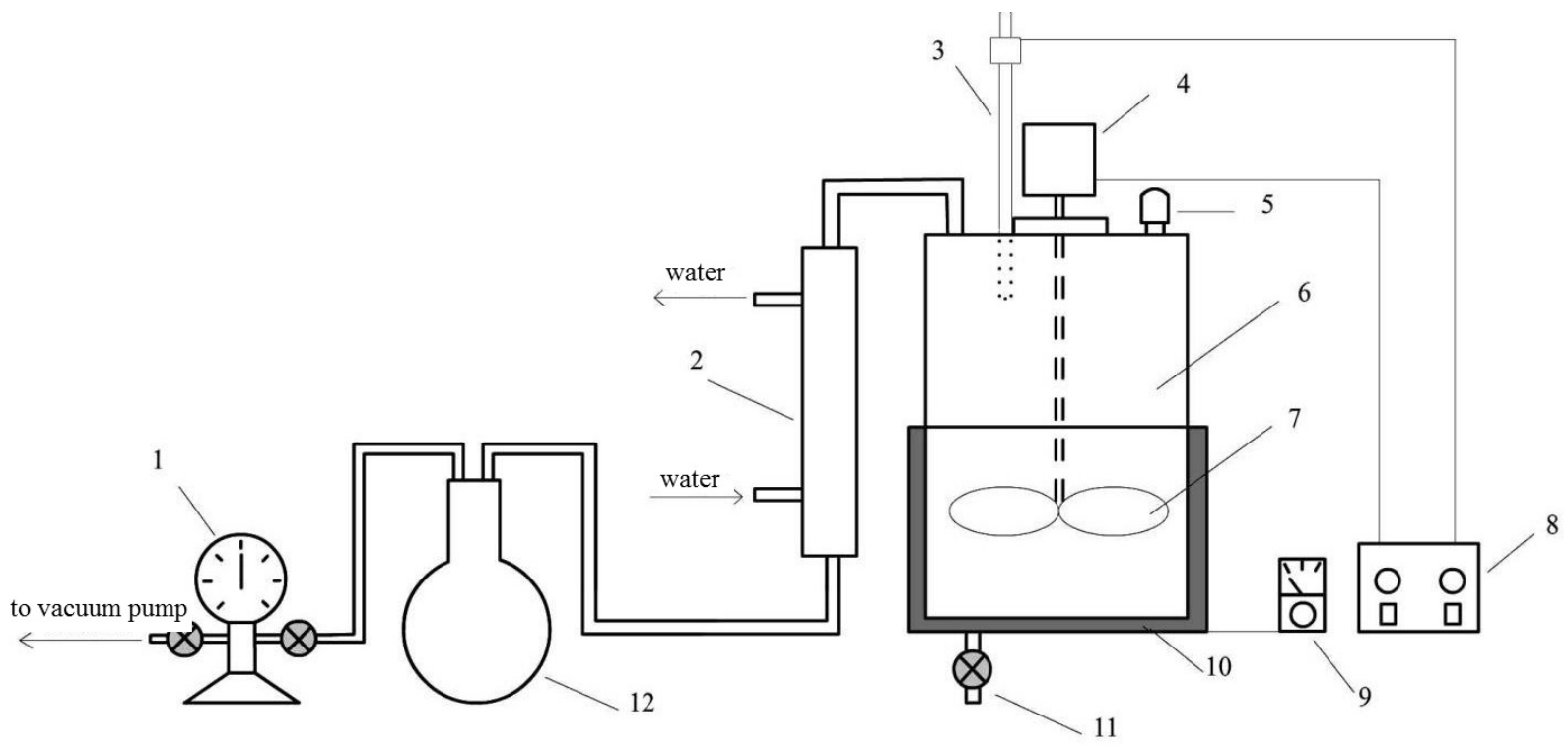

1 - manometer; 2 - condenser; 3 - top thermometer; 4 - electric engine; 5 - neck; 6 - reactor; 7 - stirrer; 8 - control unit; 9 - lower thermometer; 10 - tube electro heater; $11-$ drain valve; 12 - receiver

Figure 1. Scheme of the laboratory reactor for producing road bitumen 
This scheme is not fundamentally different from the one realized on an industrial scale at the plant for the bitumen production of in Karaganda.

Production schedules of obtaining bitumen from coal tar consists of several stages as following:

- loading the reactor with coal tar, modifying additives and reagents;

- mixing the components using a mechanical stirrer and heating of the reactor up to $240{ }^{\circ} \mathrm{C}$ under vacuum for a certain time. Aqueous phenolic solutions, light, medium and heavy hydrocarbons through the cooling system are collected in the receiver;

- sampling for analysis;

- unloading the reactor.

We elaborated a possible alternative technological scheme for production of coal tar bitumen for intensive technology presented in Figure 2.

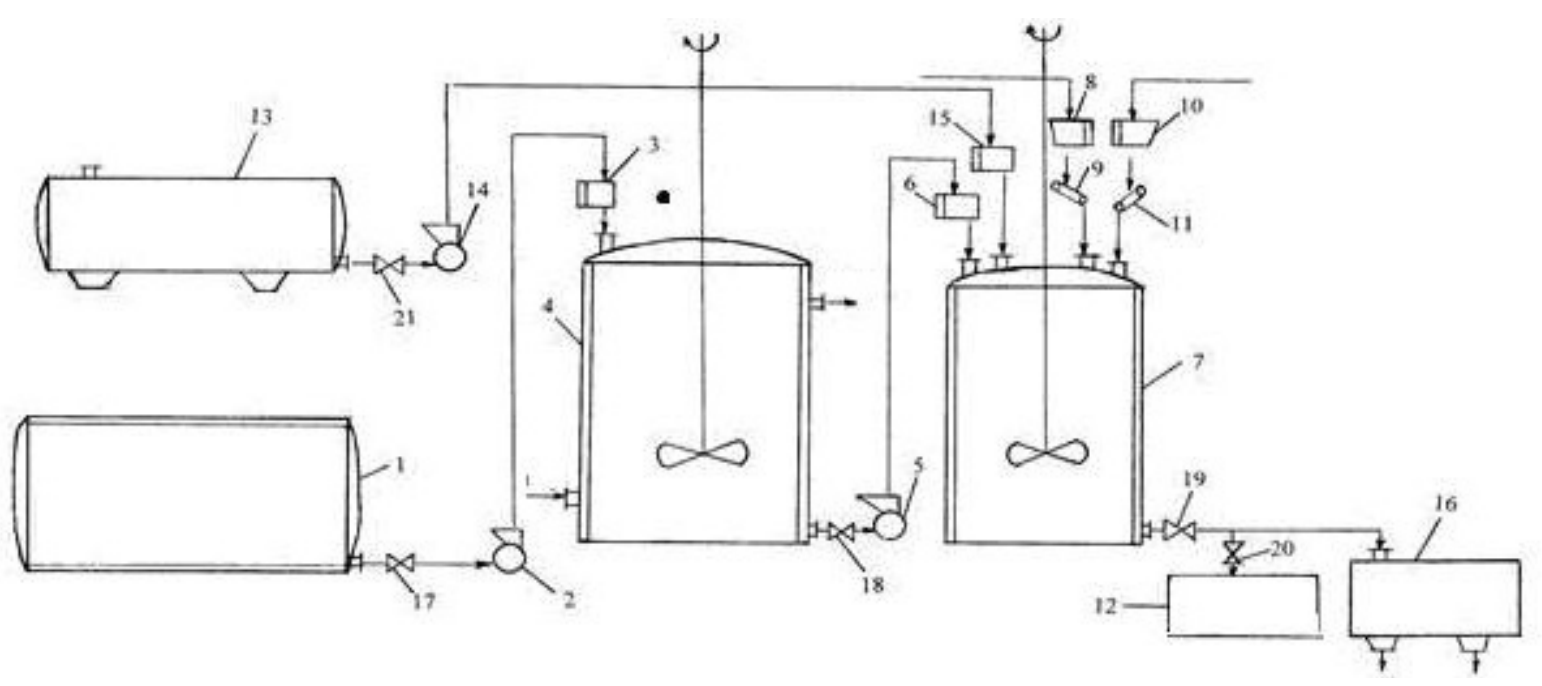

1 - tank for phenol melting; 3, 6, 15 - flowmeters; 9, 11 - weighing dosers;

2, 5, 14 - centrifugal pumps; 4,7 - reactors; 12 - bitumen packing unit; 8 - valve for feeding fuzz; 10 - valve for feeding sulphur; 13 - tank for bitumen prepared; $16-$ packaging setup; $17-21-$ valves

Figure 2. Conceptual scheme of the production of modified coal tar bitumen for road purpose by intensive technology

The operating principle of this apparatus is as follows. Polyurethane shredded wastes are loaded into the reactor 4 . From tank 1 molten phenol is fed into the reactor 4 and the mixture components react with stirring at $190^{\circ} \mathrm{C}$ to complete homogenization (approximately 3-4 hours). Coal tar after low temperature cracking at $250{ }^{\circ} \mathrm{C}$ is fed into reactor 7 from the container 13 . The temperature of $140{ }^{\circ} \mathrm{C}$ is maintained in the reactor and the speed stirrer is switched on. Ready modifier from the reactor 4 is fed in small portions over an hour to the reactor 7. Upon completion of introducing modifier the margarine production waste and elemental sulphur is fed through valves 8 and 10 . Bitumen is stirred under heating for 1.5-2 hours, then cooled and fed into the packaging unit.

Thus based of the processing results of the experiment the optimal parameters of the phenolytical modification of polyurethane elastomers blend were found. Modified products can be used as an additive in asphalt concrete mixes. Domestic and industrial wastes of polyurethane polymers served as the starting material for the modification. Synthesized modifier will significantly expand the range of high performance and to ensure adhesion properties of the road coal tar bitumen.

Advanced study of polyurethane polymers in order to expand the boundaries of their applications and the creation of new approaches to the production of practically important high molar mass compounds remains one of the most important fundamental problems of the present stage of development of polymer chemistry. 


\title{
References
}

1 Collins, J.H., \& Mikols, W.J. (1985). $60^{\text {th }}$ Meeting of the Association of Asphalt Pavement Technologists.

2 Dempsey, B.J., \& Ingersoll, J. (1980). Asphalt Concrete for Cold Regions: A Comparative Study and Analysis of Mixtures Containing Soft and Hard Grades of Asphalt Cement. Cold Regions Research and Engineering Laboratory, Hanover.

3 Rauhut, B.R., O'Quin, J.C., \& Hudson, W.R. (1976). Sensitivity Analysis of FHWA Structural Model. U.S. Department of Transportation, Vol. 1.

4 Maupin, G.W. (1976). Simple Procedure for Fatigue Characterization of Bituminous Concrete. Report FHWA-RD. U.S. Department of Transportation.

5 Mustafin, E.S., Kassenov, R.Z., Blyalev, S.A., Kaykenov, D.A., Ainabayev, A.A., \& Aitymov, A.K. (2013). Tekhnologiya polucheniya dorozhnogo bituma iz kamennougol'noi smoly Shubarkol'skogo razreza [Technology for producing bitumen from coal tar of Shubarkol coal mine]. Bulletin of the Karaganda University, Series Chemistry, 1(69), 49-53 [in Russian].

\author{
Л.М. Сугралина, И.Е. Рожковой, Л.К. Сәлкеева, Е.В. Минаева, \\ Е.К. Тайшибекова, А.В. Омашева, А.К. Сәлкеева
}

\section{Полиуретанды эластомерлерді фенолдық модификациялау таскөмірлі жол битумдары үшін полифункционалды қосындыларды алу әдісі ретінде}

\begin{abstract}
Мақалада полифункционалды қоспаларды енгізу арқылы жол битумдарының модификациясы зерттелді. Бастапқы материал ретінде осындай қосындыларды алу үшін полиуретанды полимерлердің жергілікті тұрмыстық және техногенді қалдықтары қолданылды. Модификацияны өткізудің оңтайлы жағдайын анықтау және тиімді реагентті таңдап алу мақсатымен үрдісті жүзеге асыру үшін экспериментті ықтималды-анықталған жоспарлау әдісі қолданылды. Жол асфальтты-битумды қоспаларға қосындыларды синтездеу мақсатымен эксперимент нәтижелерін өңдеу негізінде полиуретанды эластомерлердің фенолдық модификациясын өткізудің оңтайлы көрсеткіштері табылды. Битумды коспаларды алудың екі әдісін салыстыруда модификацияланған битумды өндіру кезінде модификаторды бастапқы шикізатты термиялық өңдеудің алғашқы кезеңінде енгізу жөн болады деп қорытынды жасауға мүмкіндік берді. Модификацияланған таскөмірлі битумдардың физика-механикалық қасиеттеріне жүргізілген сынамалар синтезделген модификаторды пайдалану таскөмірлі жол битумдарының жоғары адгезиялық қасиеттерін қамтамасыз етуге және жұмыс қабілеттілігі интервалын кенейтуге мүмкіндік беретінін көрсетті. Қарқынды технология бойынша модификацияланған таскөмірлі битумның мүмкін өндірісінің принципті сызбасы ұсынылды.
\end{abstract}

Кілт сөздер: полиуретанды эластомерлер, полиуретанды қалдықтарды өңдеу, фенолдық модификация, таскөмірлі шайырдың битумі, асфальтты қоспалар үшін қосындылар.

\author{
Л.М. Сугралина, И.Е. Рожковой, Л.К. Салькеева, Е.В. Минаева, \\ Е.К. Тайшибекова, А.В. Омашева, А.К. Салькеева
}

\section{Фенолитическая модификация полиуретановых эластомеров как способ получения полифункциональных добавок для каменноугольных дорожных битумов}

В статье изучена модификация дорожных битумов путем введения полифункциональных добавок. Для получения таких добавок в качестве исходного материала использовались местные бытовые и техногенные отходы полиуретановых полимеров. С целью определения оптимальных условий проведения модификации и подбора эффективного реагента для осуществления процесса был применен метод вероятностно-детерминированного планирования эксперимента. На основании обработки результатов эксперимента были найдены оптимальные параметры проведения фенолитической модификации смеси полиуретановых эластомеров с целью синтеза добавок в дорожные асфальтобитумные смеси. Сравнение двух способов получения битумных смесей позволило сделать вывод о том, что введение модификатора непосредственно в начале термической обработки исходного сырья является более целесообразным при производстве модифицированного битума. Проведенные испытания физикомеханических свойств модифицированных каменноугольных битумов показали, что применение синтезированного модификатора позволит существенно расширить интервал работоспособности и обеспечить высокие адгезионные свойства каменноугольных дорожных битумов. Была предложена принципиальная схема возможного производства модифицированного каменноугольного битума по интенсивной технологии.

Ключевые слова: полиуретановые эластомеры, переработка полиуретановых отходов, фенолитическая модификация, битум каменноугольной смолы, добавки для асфальтовых смесей. 